\title{
p53 expression in synovial sarcoma and its association with prognostic factors
}

\author{
Muhammad I. Ilmiawan, ${ }^{1}$ Puspita E. Wuyung, ${ }^{2}$ Nurjati C. Siregar ${ }^{2}$ \\ ${ }^{1}$ Master Program in Biomedical Sciences, Faculty of Medicine, Universitas Indonesia, Jakarta, Indonesia \\ ${ }^{2}$ Departement of Pathological Anatomy, Faculty of Medicine, Universitas Indonesia, Jakarta, Indonesia
}

\begin{abstract}
Abstrak
Latar belakang: Sinoviosarkoma adalah tumor agresif dan memiliki dua tipe histologi yang sering dijumpai yaitu bifasik dan monofasik. Tumor ini mengalami fusi gen SYT-SSX yang berefek menurunkan ekspresi supresor tumor p53. Prognosisnya berhubungan dengan mitosis dan diameter tumor. Penelitian ini bertujuan mempelajari bagaimana ekspresi p53 dan hubungannya dengan mitosis, diameter tumor, tipe histologi maupun faktor lainnya terkait prognosis sinoviosarkoma.
\end{abstract}

Metode: Dua puluh kasus sinoviosarkoma yang terdiri 4 monofasik dan 16 bifasik di FKUI-RSCM tahun 2005-2011dianalisis kaitan ekspresi p53 dengan mitosis sebagai faktor prognostik. Sediaan hematoksilin-eosin digunakan untuk menghitung mitosis. Sediaan blok parafin digunakan untuk menganalisis ekspresi p53 melalui imunohistokimia dan untuk mengetahui translokasi gen SYT melalui FISH (Fluorescein in situ Hybridization).

Hasil: Uji Fisher's exact menunjukkan ekspresi positif p53 berhubungan dengan diameter tumor $<5 \mathrm{~cm}$ meskipun tidak berhubungan dengan jumlah mitosis. Tipe histologi sinoviosarkoma tidak berhubungan dengan ekspresi p53 maupun mitosis. Melalui FISH diperoleh hanya 7/19 kasus mengalami translokasi gen SYT.

Kesimpulan: Pada sinoviosarkoma ekspresi p53 berhubungan dengan ukuran tumor. (Med J Indones. 2012;21:196-202)

\begin{abstract}
Background: Synovial sarcoma is an aggressive tumor and has two common histological subtype, biphasic and monophasic. It has SYT-SSX gene fusion that decreases expression of $\mathrm{p} 53$ tumor suppressor. The prognosis is associated with mitosis and tumor diameter. Therefore this study conducted to know the pattern of p53 expresion and its association with mitosis, histological subtype, and other prognosis factors.

Methods: Twenty synovial sarcoma cases consisted of 4 monophasic and 16 biphasic cases from Cipto Mangunkusumo Hospital - Faculty of Medicine, Universitas Indonesia (CMHospital-FMUI) 2005-2011 were analyzed for association of p53 expression and mitosis as prognostic factor. Haematoxylin-eosin slides were used to count mitosis. Paraffin block materials were used to analyze p53 expression by immunohistochemistry and to detect SYT gene translocation by FISH (Fluorescein in situ Hybridization).

Results: The Fisher's exact test showed that positive p53 expression was associated with tumor diameter $<5 \mathrm{~cm}$ although it was not associated with mitosis. The histological subtype has no association with p53 expression and mitosis. Unfortunately, only 7/19 cases were positive for FISH-SYT gene translocation.

Conclusion: In synovial sarcoma, p53 expression is associated with tumor diameter. (Med J Indones. 2012;21:196-202)

Keywords: Mitosis, p53, synovial sarcoma, SYT-SSX fusion gene
\end{abstract}

Synovial sarcoma is an aggressive tumor than can recur and have metastasis with low surviral rate. ${ }^{1}$ The tumor is commonly found in extremity and surgery represents the primary therapy modality. Thus the therapy can render disability to the patient. ${ }^{2}$

Synovial sarcoma has two cellular type, spindle cell and epiteloid cell. The proportion of both cell are varied and can be classified as several histological subtypes: biphasic subtype, monophasic subtype (monophasic fibrous or rarely monophasic epithelial), and poor differentiated subtype. ${ }^{3}$

The tumors contain characteristic translocation $\mathrm{t}(\mathrm{X} ; 18)$ (p11.2;q11.2) that produce fusion of SYT gene in chromosome 18 with member of SSX gene family in X chromosome. Three of nine SSX gene family involve in SYT-SSX translocation are SSX1, SSX2, or SSX4. The presence of SYT-SSX transcript in almost all synovial sarcoma cases indicated that the fusion protein play role as tumor etiology. ${ }^{3}$ D' Arcy et al reported that SYT-SSX1 fusion protein can enhance stability of HDM2. HDM2 incresases p53 ubiquitinization and p53 degradation. Moreover, SYT-SSX1 shows pro-survival activity and increases cell growth. ${ }^{4}$

p53 plays important role to maintain genome integrity. Upon DNA damage, the p53 will be activated. This can leads to cell cycle arrest and induction of DNA repair. If DNA repair fails, p53 triggers apoptosis. In cells with loss or mutation of $\mathrm{p} 53$, DNA damage does not induce DNA repair and cell cycle arrest. The genetically 
damaged cells proliferate and may leads to malignant neoplasms..$^{5,6}$

It has been reported that the prognosis associated with mitosis $<10 / 10 \mathrm{HPF}$ (high power field), tumor diameter $<5 \mathrm{~cm}$, no necrosis, patients age $\leq 20$ years and if tumor can be eradicated by surgery. ${ }^{1}$ To date, factors that associated with the tumor patogenesis and prognosis still investigated. Therefore the objective of this study was to know the pattern of p53 expresion and to evaluate its association with mitosis, histological subtype, and other prognosis factors.

\section{METHODS}

\section{Diagnosis}

Twenty cases were retrieved from the archives of Anatomical Pathology Department ofCipto Mangunkusumo Hospital - Faculty of Medicine Universitas Indonesia (CMHospital-FMUI) 2005-2011. The hematoxylin-eosin slides were re-examined by a pathologist of soft tissue and Bone Division of Anatomical Pathology CMHospital-FMUI. Patients age, sex, tumor site and tumor diameter were noted. One representative paraffin block per tumour was selected for immunostaining and FISH (Fluorescence in situ hybridization).

\section{p53 expressions}

The tumor p53 expression were observed through immunohistochemistry. The cases were grouped as negative p53 expression if the stain intensity 0 -weak or if the tumor cell stained less than $10 \%$ and as possitive p53 expression if the nuclei stained moderate-strong and the tumor cell stained $10 \%$ or more. The examination performed through digital camera Olympus DP25 from $10 \mathrm{HPF}$ (40x objective lens) Olympus BX51 microscop and then counted with ImageJ 1.46n software.

Paraffin block materials were cut 2-5 $\mu \mathrm{m}$ thick, mounted on glass slides coated by poly-1-lysine. The sections were deparafinized in xylene and rehydrated in ethanol, and endogenous peroxidase was blocked by methanol containing $0,5 \% \mathrm{H}_{2} \mathrm{O}_{2}$ for $30 \mathrm{~min}$. For antigen retrieval, sections were pretreated with citrate buffer, at power level 8 and 1 each for $5 \mathrm{~min}$ in a microwave oven. For blocking unspesific staining, the sections were treated with bacground sniper (Biocare) for $30 \mathrm{~min}$. The sections were incubated with primary antibody (1:750, monoclonal mouse anti-human p53 protein, M7001, DAKO Cytomation) at room temperature for $60 \mathrm{~min}$. Then followed by treating with a Starr Trek universal HRP detection system (Biocare). The sections were finally reacted with Betazoid DAB chromogen solution (Biocare) and counterstained with haematoxylin.

\section{Mitosis}

The haematoxylin-eosin slides (which were coded) were used to count mitosis (metaphase or anaphase) microscopically on $10 \mathrm{HPF}$ (40x objective lens). The cases were grouped as mitosis $<10 / 10 \mathrm{HPF}$ group and $\geq 10 / 10$ HPF group. The counting was done three times, one time by the author and twice by co-author. The results then summed and averaged.

\section{Translocation $t(X ; 18)(p 11.2 ; q 11.2)$}

Translocation $\mathrm{t}(\mathrm{X} ; 18)(\mathrm{p} 11.2 ; \mathrm{q} 11.2)$ detected by FISH method using ZytoLight ${ }^{\circledR}$ SPEC SYT Dual Color Break Apart Probe (ZytoVision). This reagent contains two probes, the first probe labeled with orange fluorophore hybridized with sequences distal to the SYT gene and the second probe labeled with green fluorophore hybridized with sequences proximal to the SYT gene. In cell without translocation involving SYT gene, two pairs of green/orange fusion signals appeared. Otherwise if the translocation involving one of SYT gene, one separate green signal and orange signal by a distance more than diameter of one signal appeared (Figure 1). The cases were grouped as FISH positive if the translocations were counted $\geq$ $20 \%$ of 50 nucleus.

Paraffin block materials were cut 2-5 $\mu \mathrm{m}$ thick, mounted on glass slides coated by poly-1-lysine. Sections were incubated on a hot plate at $60^{\circ} \mathrm{C}$ for 2 hours and at $70^{\circ} \mathrm{C}$ for $10 \mathrm{~min}$. Sections were deparafinized in xylene $(2 \mathrm{x}$ for $10 \mathrm{~min})$ and rehydrated in ethanol $(100 \%, 100 \%$, $90 \%$, and $70 \%$, each for $5 \mathrm{~min}$ ) followed by washing in distilled water ( $2 \mathrm{x}$ for $2 \mathrm{~min}$ ). Sections were then incubated in pre-warmed heat pretreatment solution cytric (PT1, ZytoVision) at $98^{\circ} \mathrm{C}$ for $15 \mathrm{~min}$ and washed in distilled water ( $2 \mathrm{x}$ for $2 \mathrm{~min}$ ). For proteolysis, sections were reacted with pepsin solution (ES1, ZytoVision) and incubated at $37^{\circ} \mathrm{C}$ in a humidity chamber for 10 min. Then followed by washing with wash buffer ssc (WB1, ZytoVision) for $5 \mathrm{~min}$ and with distilled water for $1 \mathrm{~min}$. Sections were dehydrated in ethanol $(70 \%$, $90 \%$, and $100 \%$ each for $1 \mathrm{~min}$ ) and air dried. The probe were applied to sections, covered with a coverslip and sealed with rubber cement. Sections were denatured at $75^{\circ} \mathrm{C}$ for $10 \mathrm{~min}$ on a hot plate. Followed by hybridization overnight at $37^{\circ} \mathrm{C}$ in humidity chamber. Sections were washed with pre-warmed wash buffer A (WB2, ZytoVision) at $37^{\circ} \mathrm{C}$ for $3 \mathrm{~min}$ and again twice for 5 min. Sections were air dried in the dark then reacted with DAPI/Antifade (MT1, ZytoVision). Sections were covered with coverslip, sealed with nail varnish and incubated in room temperature for $15 \mathrm{~min}$. The samples were analyzed under a fluorescent microscope (100x objective lens with immersion oil, Olympus BX51) 


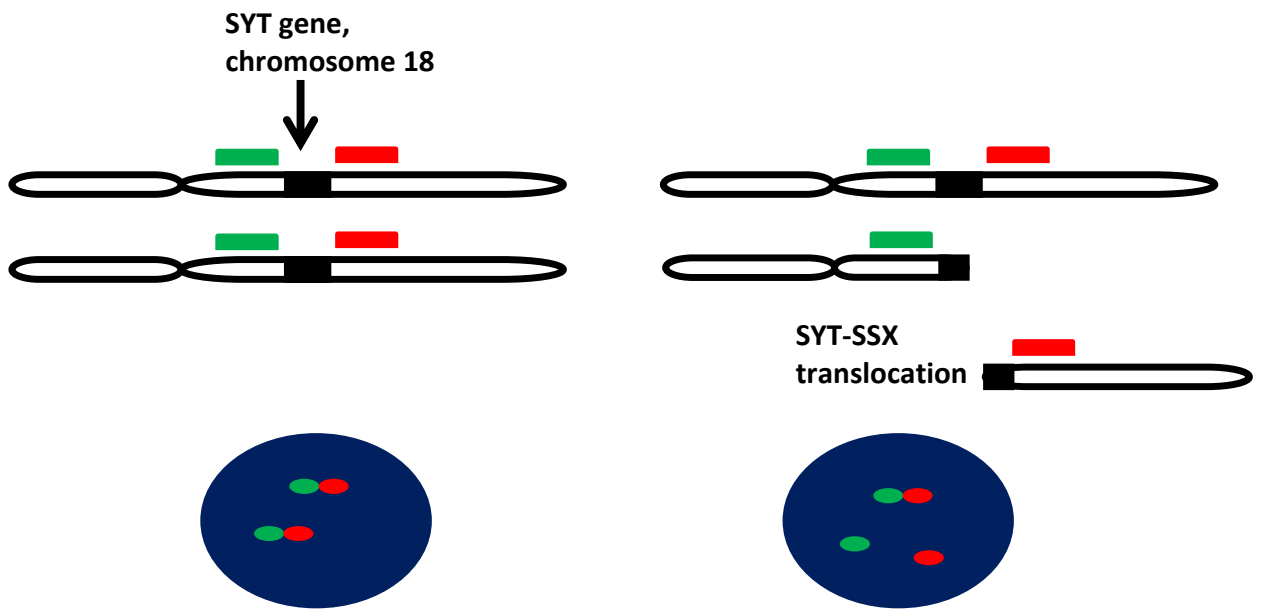

Figure 1. SYT gene translocation in chromosome 18. At the top left, 2 probes were labeled with 2 different fluorochromes (green and red), they hybridize with the proximal and distal parts of SYT gene. In the absence of SYT gene translocation showed two pairs of red and green signals close to each other (bottom left). While if there was a SYT gene translocation (top right), then showed a sparated red and green signal (bottom right)

and digitally photographed (Olympus DP25 camera). The pictures were then edited and counted with ImageJ 1.46 noftware. ${ }^{7}$

\section{Statistical analysis}

Fisher's exact tests were used to analyze differences between independent variables. Differences were considered significant if $p<0.05$. The software MYSTAT 12 Version 12.02 .00 was used for statistical analysis.

\section{RESULTS}

The cases number were equal in female and male, most tumor cases were located at extremity. In one case, the tumor location was unknown because the medical record was incomplete. Majority of the cases were histologically biphasic type. Tumor diameter was classified as $<5 \mathrm{~cm}$ (9 cases) and $\geq 5 \mathrm{~cm}$ (10 cases) while in one case, the tumor diameter was unknown (Table 1).

The results of tumor p53 expresion, mitosis and FISH can be seen in table 2 . The p53 positive cases were counted more than negative cases (Figure 2). Number of cases with mitosis $\geq 10 / 10 \mathrm{HPF}$ was higher than cases with mitosis $<10 / 10$ HPF. The results of FISH revealed, $7 / 19$ cases positive for SYT gene translocation (Figure 3). One case can not be analyzed because of pepsin overdigestion and was not restained because the probe was insufficient.
Table 1. Clinical datas and histological subtype

\begin{tabular}{lc}
\hline Clinical data & \\
\hline Age & 15-70 year (mean 41.3 year) \\
Gender & 10 \\
$\quad$ Female & 10 \\
$\quad$ Male & \\
Tumor location & 6 \\
$\quad$ Upper extremity & 8 \\
$\quad$ Lower extremity & 2 \\
Head and neck & 3 \\
Trunk & 1 \\
Unknown & \\
Tumor diameter & 9 \\
$\quad<5$ cm & 10 \\
$\geq 5$ cm & 1 \\
Unknown & \\
Histological subtype & \\
Monophasic & 4 \\
$\quad$ Biphasic & 16 \\
\hline
\end{tabular}

Tumor diameter was associated with p53 expression $(\mathrm{p}<0.05)$ although tumor diameter was not associated with mitosis. There was no association between $\mathrm{p} 53$ expression with mitosis. There was no association between p53 or mitosis with histological subtype of synovial sarcoma, with tumor location, and with gender (Table 3). Of the seven FISH positive cases, p53 expression was not associated with mitosis (Table 4). 


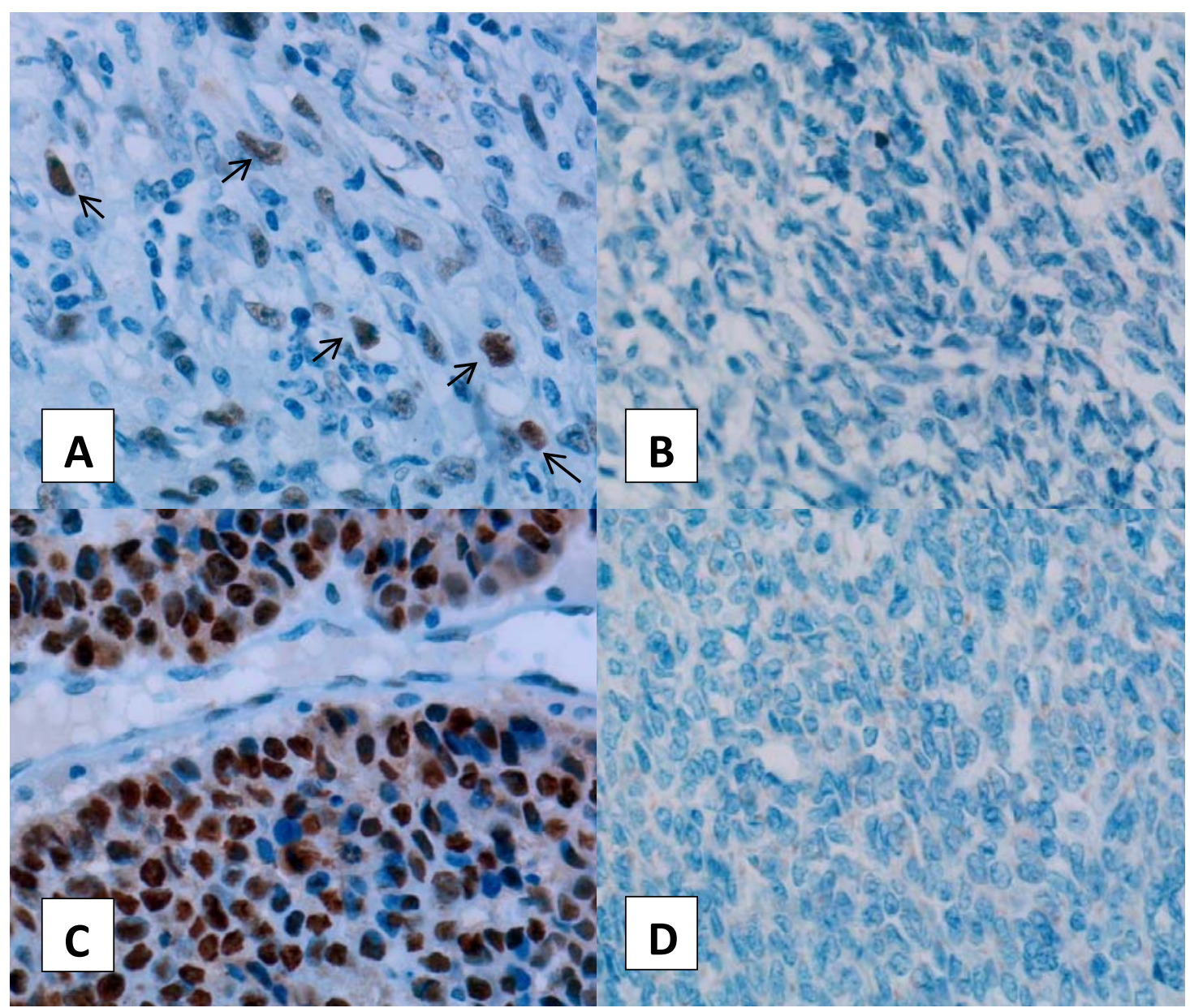

Figure 2. p53 expression in synovial sarcoma. (A) p53 positive expression case, several nucleus were brown stained by DAB (arrows), (B) Case with negative p53 expression, (C) positive control (breast tumors), (D) negative control. (Immunohistochemistry staining , 40x objective lens)

Table 2. p53 expression, mitosis and SYT gene translocation

\begin{tabular}{lc}
\hline Examination & Cases \\
\hline p53 expression & \\
Positive & 11 \\
Negative & 9 \\
Mitosis & \\
$<10 / \mathrm{HPF}$ & 12 \\
$\geq 10 / \mathrm{HPF}$ & 8 \\
SYT gene translocation & \\
Positive & 7 \\
Negative & 12 \\
Can not be analyzed & 1 \\
\hline
\end{tabular}

\section{DISCUSSION}

In this study, synovial sarcoma cases occurred in the age ranged from young to old and their average age was adult, while the proportion of cases in both sexes were equal. Characteristics of the subjects were similar to those reported by Oda et al. ${ }^{8}$ In this study, the tumor was found at the extremity, head and neck region and trunk. Most tumors were located in the extremity. These results were similar to those reported by Amary et $\mathrm{al}^{9}$ and Fang et al. ${ }^{10}$

Some cases expressing p53. This result was similar to that reported by Oda et $\mathrm{al}^{8}$ and Schneider-Stock et al. ${ }^{11}$ In synovial sarcoma, p53 should decreases as reported by D'Arcy et $\mathrm{al}^{4}$, though the soft tissue tumors may have increased expression of p53 and this is associated with poor prognosis. ${ }^{12}$ Several processes can increase p53 expression such as telomere shortening, DNA damage, oxidative stress, oncogenic stress and Ras activation. ${ }^{13}$ Therefore in this study possible causes need to be further investigated. Moreover Oda et $\mathrm{al}^{8}$ and SchneiderStock et $\mathrm{al}^{11}$ reported in some cases with p53 expression have no p53 mutated.

Expression of p53 were observed in this study due to the increased expression of mutant p53 can not be ruled out, because the primary antibody that we were used can reacts to both p53 wild-type and mutant. ${ }^{14}$ Oda et 


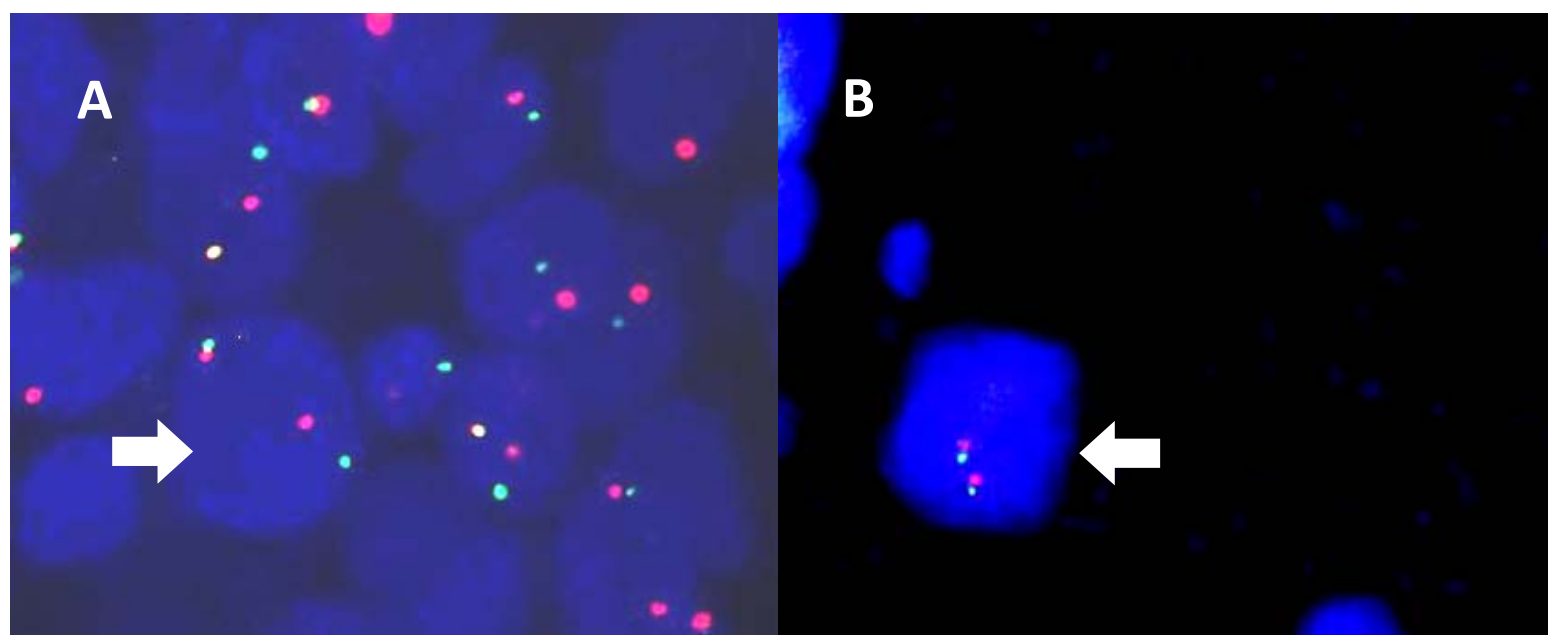

Figure 3. SYT gene translocation. (A) SYT gene translocation in the nuclei, white arrow pointing a nuclei with a green signal (representing proximal segment of SYT gene) and a red signal (representing distal segment of SYT gene) separated by a distance exceeding diameter of one signal. (B) nuclei without SYT gene translocation, white arrow pointing nuclei with two pairs of green signal and red signal located adjacent (FISH, 100x objective lens with immersion oil).

Table 3. Statistical analysis of p53 expression and mitosis

\begin{tabular}{|c|c|c|c|c|c|c|}
\hline & \multicolumn{2}{|c|}{$\mathrm{p} 53$} & \multirow{2}{*}{$\mathrm{p}$} & \multicolumn{2}{|c|}{ Mitosis } & \multirow{2}{*}{$\mathrm{p}$} \\
\hline & Positive & Negative & & $<10 / \mathrm{HPF}$ & $\geq 10 / \mathrm{HPF}$ & \\
\hline \multicolumn{7}{|l|}{ p53 } \\
\hline Positive & & & & 8 & 3 & 0,362 \\
\hline Negative & & & & 4 & 5 & \\
\hline \multicolumn{7}{|l|}{ Tumor diameter } \\
\hline$<5 \mathrm{~cm}$ & 8 & 1 & $0,005^{*}$ & 6 & 3 & 0,650 \\
\hline$\geq 5 \mathrm{~cm}$ & 2 & 8 & & 5 & 5 & \\
\hline \multicolumn{7}{|l|}{ Tumor Location } \\
\hline Upper extremity & 4 & 2 & 0,592 & 3 & 3 & 1,000 \\
\hline Lower extremity & 3 & 5 & & 5 & 3 & \\
\hline Trunk & 1 & 2 & & 2 & 1 & \\
\hline Head and neck & 2 & 0 & & 1 & 1 & \\
\hline Unknown & 1 & 0 & & 1 & 0 & \\
\hline \multicolumn{7}{|l|}{ Histological subtype } \\
\hline Monophasic & 1 & 3 & 0,285 & 1 & 3 & 0,255 \\
\hline Biphasic & 10 & 6 & & 11 & 5 & \\
\hline \multicolumn{7}{|l|}{ Gender } \\
\hline Female & 5 & 5 & 1,000 & 5 & 5 & 0,650 \\
\hline Male & 6 & 4 & & 7 & 3 & \\
\hline \multicolumn{7}{|c|}{ SYT gene translocation } \\
\hline Positive & 2 & 5 & & 3 & 4 & \\
\hline Negative & 8 & 4 & & 5 & 7 & \\
\hline
\end{tabular}

p: Fisher's Exact test two-tail, *: significant

$\mathrm{al}^{8}$ and Schneider-Stock et $\mathrm{al}^{11}$ reported $\mathrm{p} 53$ expression in synovial sarcoma some are mutants. In addition to functioning as a tumor suppressor p53 can serve as an oncoprotein if it is mutated. ${ }^{15}$ Although Oda et $\mathrm{al}^{8}$ also reported no association between $\mathrm{p} 53$ expression with $\mathrm{p} 53$ mutations, in these study whether p53 mutations were involved in the tumor pathogenesis was not known.

In synovial sarcoma high number of mitosis increases histological degree with poor prognosis. ${ }^{16}$ In this study 
Table 4. p53 expression and mitosis of the cases with SYT gene translocation

\begin{tabular}{cccc}
\hline & \multicolumn{2}{c}{ Mitosis } & \\
\cline { 2 - 3 } & $<10 / \mathrm{HPF}$ & $\geq 10 / \mathrm{HPF}$ & \\
\hline $\mathrm{p} 53$ & 2 & 0 & 0,429 \\
Positive & 2 & 3 & \\
Negative & 2 & \\
\hline
\end{tabular}

p: Fisher's Exact test two-tail

there was no association between $\mathrm{p} 53$ expression with mitosis, this is similar as reported by Oda et al. ${ }^{8}$ This may indicated that p53 signaling pathway was not the only major factor affecting tumor mitosis. Haldar et $\mathrm{al}^{3}$ explain there are other signaling pathways that influence synovial sarcoma growth. SYT-SSX fusion proteins can increase expression of factors that promote cell proliferation, such as cyclin D1, $\beta$-catenin, IGF2, IGF-1R, ERK1, ERK2, p-ERK and can decreased expression of factors that suppress cell proliferation, such as EGR1 and COM1. ${ }^{17}$

Because this study was conducted in population different from previous studies, there was possibility p53 and HDM2 polymorphism influence tumor mitosis. Although this is not the cause of malignancy, polymorphism may affect both protein activity and may influence tumor pathogenesis as well. ${ }^{18}$

In this study, tumor diameter was not associated with mitosis. Tumor diameter should relate to the number of mitosis, the higher mitotic number the greater tumor size. Therefore in this study tumor proliferation should be further confirmed by Ki-67 examination.

Almost all synovial sarcoma presents translocation between SYT gene on chromosome 18 with SSX gene on chromosome $\mathrm{X} .{ }^{2}$ This translocation can be detected by FISH or RT-PCR. ${ }^{19}$ FISH method as described in figure 1 has been proved by Amary et $\mathrm{al}^{9}$ and Motoi et al. ${ }^{20}$ Unfortunately, in this study a positive FISH obtained only in $7 / 19$ cases. The FISH results was different from the number of histopathologic diagnosis. Amary et $\mathrm{al}^{9}$ reported that not all cases showed SYT gene translocation by FISH. This is because the FISH method may occur difficulty if one signal partner disappears or if there are SYT gene amplification, we also experienced the same thing. Amary et $\mathrm{al}^{9}$ reported in some of FISH negative cases, SYT-SSX fusion transcripts can be detected by PCR or RT-PCR. There was a possibility that the FISH negative cases were not synovial sarcoma as tumor histologically may resemble malignant peripheral nerve sheath tumor. ${ }^{2}$ Amary et $\mathrm{al}^{9}$ reported the cases with negative SYT-SSX fusion gene based on other tests obtained diagnosis other than synovial sarcoma. Therefore, in this study further investigations are needed to confirm the results of negative FISH.

Of seven positive FISH cases showed no association between p53 expression with mitosis. Mitosis can be influenced by SYT-SSX fusion gene subtype. ${ }^{16}$ Inagaki et $\mathrm{al}^{16}$ reported SYT-SSX1 fusion gene associated with high expression of Ki-67 and high mitotis compared with SYT-SSX2 fusion gene. Although there was no association between SYT-SSX fusion gene subtype with p53 expression, ${ }^{16}$ in this study to investigate the role of SYT-SSX fusion gene subtype, PCR or qRTPCR is needed.

SYT-SSX fusion gene subtype associated with synovial sarcoma histological subtype, mitosis and Ki67. ${ }^{16}$ In this study showed no correlation between histological type with p53 expression and with mitosis. These results were consistent with reports of Schneider-Stock et $\mathrm{al}^{11}$ and Oda et al. $^{8}$ SYT-SSX1 translocation subtype associated with glandular epithelial differentiation than SYT-SSX2. Expression of E-cadherin reported to be associated with the phenotype of SYT-SSX1 and glandular biphasic morphology. ${ }^{12}$ Furthermore Derksen et $\mathrm{al}^{21}$ reported that the loss of expression of E-cadherin and p53 synergize to form breast tumors that grow faster and invasive in mice. Therefore role of both factors in histological subtypes of synovial sarcoma may be important and need to be further studied.

In this study, there was an association between tumor diameter $<5 \mathrm{~cm}$ with positive p53 expression. The result was in contrast to reports of Oda et al. ${ }^{8}$ This indicated that positive p53 expression suppresses tumor growth and conversely negative $\mathrm{p} 53$ expression promotes tumor growth. Wild-type $\mathrm{p} 53$ has function as a tumor suppressor, therefore it was possible that p53 expressed in this study were wild-type. This finding should be further clarified by performing p53 mutation examination.

In this study showed no significant difference p53 expression and mitosis between male and female patients. This was similar as reported by Oda et al. ${ }^{8}$ This indicated that sex hormones were not involved in tumor patogensis. These finding is supported by reports of Bhargava et $\mathrm{al}^{22}$ that of the 16 cases were studied revealed no expression of estrogen receptor and progesterone receptor found only in one case.

In conclusion, the positive p53 expression in synovial sarcoma associated with tumor diameter $<5 \mathrm{~cm}$, although not related to mitosis. While between biphasic and monophasic subtype of synovial sarcoma there is no difference of p53 expression and mitosis. 


\section{Acknowledgments}

We would like to thank ZytoVision GmbH Bremerhaven Germany and assisted by PT. Biozatix Indonesia who have given the FISH reagents (ZytoLight SPEC SYT Dual Color Break Apart FISH Probe and ZytoLightTissue Implementation Kit) for SYT gene translocation examination in this study.

\section{REFERENCES}

1. World Health Organization. International agency for research on cancer. Fletcher C. Pathology and genetics of tumours of soft tissue and bone. Lyon: IARC Press; 2002.

2. Eilber FC, Dry SM. Diagnosis and management of synovial sarcoma. J Surg Oncol. 2008;97(4):314-20.

3. Haldar M, Randall RL, Capecchi MR. Synovial sarcoma: from genetics to genetic-based animal modeling. Clin Orthop Relat Res. 2008;466(9):2156-67.

4. D'Arcy P, Maruwge W, Ryan BA, Brodin B. The oncoprotein SS18-SSX1 promotes p53 ubiquitination and degradation by enhancing HDM2 stability. Mol Cancer Res. 2008;6(1):127-38.

5. Robbins S. Robbins and Cotran pathologic basis of disease. 8th ed. Philadelphia PA: Saunders/Elsevier; 2010.

6. Ozaki T, Nakagawara A. p53: the attractive tumor suppressor in the cancer research field. J Biomed Biotechnol [Internet]. 2011;2011:[about 13 p]. Available from: http://www. hindawi.com/journals/biomed/2011/603925/.

7. Abramoff M, Magelhaes P, Ram S. Image processing with ImageJ. Biophotonics International. 2004;11(7):36-42.

8. Oda Y, Sakamoto A, Satio T, Kawauchi S, Iwamoto $\mathrm{Y}$, Tsuneyoshi M. Molecular abnormalities of p53, MDM2, and H-ras in synovial sarcoma. Mod Pathol. 2000;13(9):994-1004.

9. Amary MFC, Berisha F, Bernardi FDC, Herbert A, James M, Reis-Filho JS, et al. Detection of SS18-SSX fusion transcripts in formalin-fixed paraffin-embedded neoplasms: analysis of conventional RT-PCR, qRT-PCR and dual color FISH as diagnostic tools for synovial sarcoma. Mod Pathol. 2007;20(4):482-96.

10. Fang Z, Chen J, Teng S, Chen Y, Xue R. Analysis of soft tissue sarcomas in 1118 cases. Chin Med J. 2009;122(1):51-3.

11. Schneider-Stock R, Onnasch D, Haeckel C, Mellin W, Franke D-S, Roessner A. Prognostic significance of p53 gene mutations and p53 protein expression in synovial sarcomas. Virchows Archiv. 1999;435(4):407-12.

12. Oda Y, Tsuneyoshi M. Recent advances in the molecular pathology of soft tissue sarcoma: implications for diagnosis, patient prognosis, and molecular target therapy in the future. Cancer Sci. 2009;100(2):200-8.

13. Shangary S, Wang S. Targeting the MDM2-p53 interaction for cancer therapy. Clin Cancer Res. 2008;14(17):5318-24.

14. Monoclonal mouse anti-human p53 protein, clone DO-7 [Internet]. [cited 2012 Jun 1]. Available from: http:// www.dako.com/dist/ar38/p105510/prod_products. $\underline{\mathrm{htm}}$ ? setCountry $=$ true \& purl $=\operatorname{ar} 38 / \mathrm{p} 105510 / \mathrm{prod}$ products.htm.

15. Suzuki K, Matsubara H. Recent advances in p53 research and cancer treatment. J Biomed Biotechnol [Internet]. 2011;2011:[about 7 p]. Available from: http://www.hindawi. com/journals/biomed/2011/978312/.

16. Inagaki H, Nagasaka T, Otsuka T, Sugiura E, Nakashima N, Eimoto T. Association of SYT-SSX fusion types with proliferative activity and prognosis in synovial sarcoma. Mod Pathol. 2000;13(5):482-8.

17. Przybyl J, Jurkowska M, Rutkowski P, Debiec-Rychter M, Siedlecki JA. Downstream and intermediate interactions of synovial sarcoma-associated fusion oncoproteins and their implication for targeted therapy. Sarcoma [Internet]. 2012;2012:[about 13 p]. Available from: http://www. hindawi.com/journals/srcm/2012/249219/.

18. Whibley C, Pharoah PDP, Hollstein M. p53 polymorphisms: cancer implications. Nat Rev Cancer. 2009;9(2):95-107.

19. Bruce R P. Recent advances in the molecular diagnosis of paediatric soft tissue sarcomas. Diagnostic Histopathology. 2011;17(1):25-35.

20. Motoi T, Kumagai A, Tsuji K, Imamura T, Fukusato T. Diagnostic utility of dual-color break-apart chromogenic in situ hybridization for the detection of rearranged SS18 in formalin-fixed, paraffin-embedded synovial sarcoma. Hum Pathol. 2010;41(10):1397-404.

21. Derksen PWB, Liu X, Saridin F, van der Gulden H, Zevenhoven J, Evers B, et al. Somatic inactivation of E-cadherin and p53 in mice leads to metastatic lobular mammary carcinoma through induction of anoikis resistance and angiogenesis. Cancer Cell. 2006;10(5):437-49.

22. Bhargava R, Shia J, Hummer AJ, Thaler HT, Tornos C, Soslow RA. Distinction of endometrial stromal sarcomas from "hemangiopericytomatous" tumors using a panel of immunohistochemical stains. Mod Pathol. 2005;18(1):40-7. 